\title{
PENGARUH SPA BAYI TERHADAP PENINGKATAN BERAT BADAN BAYI USIA 4-6 BULAN DI WILAYAH KERJA PUSKESMAS TAPIAN DOLOK KABUPATEN SIMALUNGUN
}

\author{
Parmiana Bangun \\ Politeknik Kesehatan Kementerian Kesehatan RI Medan Jurusan Kebidanan \\ Program Studi Kebidanan Pematangsiantar \\ email: parmianabangun83@gmail.com
}

\begin{abstract}
Infan is the period as well as the time of Christ's development. It is said to be a critical period because this period is very short for the environment and it is said to be a development period because infancy is not very short and can be repeated again. The most important period of child development is infancy and toddlerhood. In infancy / toddler there is a basic growth that will determine the next child's development. Infancy is the first month of life, the baby will adapt to the environment, changes in blood circulation, and begin to work the organs of the body, and in post-neonatal the baby will experience very fast growth. One way to stimulate growth and development in children is to use the baby solus per aqua (SPA) technique. Babies who are given SPA Babies will certainly grow and develop differently from the growth and development of babies who are not given SPA Babies. This is because the Baby SPA series aims to awaken the baby's sensory and motor nerves early with certain stimuli so that babies can grow actively and be more optimal both physically and mentally. This study aims to obtain an overview of the effect of Infant SPA on weight gain aged 4 to 6 months, Measuring the weight gain of infants aged 4 to 6 months who receive and Infant SPA and those who do not receive massage and Infant SPA at the Tapian Dolok Health Center, Simalungun Regency. The hypothesis in this study is that the increase in the weight of the babies who received the Baby Spa was greater than the standard deviation of the weight gain of 36.9 with a mean difference of 48.7 grams between the two groups. The sample size obtained is 12 respondents so that the number of samples will be increased to 30 according to the minimum sample that can be analyzed statistically. So the intervention group was 30 babies and the control group was 30 babies. The results showed that there was an effect of SPA for infants on weight gain of infants at the age of 4 to 6 months. This study is expected to provide knowledge to mothers who have babies aged 46 months the importance of SPA for babies to the baby's weight gain.
\end{abstract}

Keywords: Weight; SPA in infants

\begin{abstract}
ABSTRAK
Masa bayi adalah masa keemasan sekaligus masa kristus perkembnagan seseorang. Dikatakan masa kritis karena pada masa ini bayi sangat peka terhadap lingkungan dan dikatakan masa keemasan karena masa bayi berlangsung sangat singkat dan tidak dapat diulang kembali. Masa bayi merupakan bulan pertama kehidupan karena bayi akan mengalami adaptasi terhadap lingkungan, perubahan sirkulasi darah, serta mulai berfungsinya organ - organ tubuh, dan pada pasca neonatus bayi akan mengalami pertumbuhan yang sangat cepat. Salah satu cara untuk menstimulasi pertumbuhan dan perkembangan pada anak yaitu dengan menggunakan teknik baby solus per aqua (SPA). Bayi yang diberikan $S P A$ Bayi tentu akan berbeda tumbuh kembangnya dengan tumbuh kembang bayi yang tidak diberi SPA Bayi. Hal ini dikarenakan rangkaian SPA Bayi bertujuan merangsang saraf sensorik dan motorik bayi lebih dini dengan stimulus stimulus tertentu sehingga bayi dapat tumbuh aktif serta lebih optimal baik secara fisik maupun mentalnya. Penelitian bertujuan Memperoleh gambaran tentang pengaruh $S P A$ Bayi terhadap peningkatan berat badan usia 4 sampai 6 bulan, Mengukur peningkatan berat badan bayi usia 4 sampai 6 bulan yang menerima dan SPA Bayi maupun yang tidak menerima pemijatan dan SPA Bayi di Puskesmas Tapian dolok Kabupaten Simalungun. Hipotesis pada penelitian ini adalah peningkatan berat badan bayi yang mendapatkan Spa Bayi lebih besar dari pada standar deviasi kenaikan berat badan sebesar 36,9 dengan selisih rerata kedua kelompok sebesar 48, 7 gram. Besar sampel didapatkan 12 responden sehingga jumlah sampel akan ditingkatkan menjadi 30 sesuai dengan minimal sampel yang dapat dianalisis secara statistik. Jadi kelompok intervensi 30 bayi dan kelompok kontrol 30 bayi. Hasil penelitian menunjukkan ada pengaruh SPA bayi terhadap Kenaikan berat badan bayi pada usia 4 samapai 6 bulan. Penelitian ini diharapkan dapat memberikan pengetahuan pada ibu yang memiliki bayi usia 4 sampai 6 bulan akan pentingnya $S P A$ bayi untuk penambahan berat badan bayi.
\end{abstract}

Kata kunci : Penamban berat badan; SPA pada bayi 


\section{PENDAHULUAN}

\section{Latar Belakang}

Masa bayi adalah masa keemasan sekaligus masa kritis perkembangan seseorang. Dikatakan masa kritis karena pada masa ini bayi sangat peka terhadap lingkungan dan dikatakan masa keemasan karena masa bayi berlangsung sangat singkat dan tidak dapat diulang kembali. ${ }^{(8)}$

Masa paling penting dari tumbuh kembang anak adalah masa bayi dan balita. Pada masa bayi/balita terjadi pertumbuhan dasar yang akan menentukan perkembangan anak selanjutnya. Usia perkembangan bayi terbagi 2 yaitu, neonatus sejak lahir sampai usia 28 hari dan bayi dari usia 29 hari sampai 12 bulan. $^{(2)}$ Sedangkan menurut teori Roesli U ${ }^{(9)}$ bayi adalah anak usia 0 sampai 12 bulan. Masa bayi merupakan bulan pertama kehidupan karena bayi akan mengalami adaptasi terhadap lingkungan, perubahan sirkulasi darah, serta mulai berfungsinya organ - organ tubuh, dan pada pasca neonatus bayi akan mengalami pertumbuhan yang sangat cepat.

Setiap bayi mengalami tahap pertumbuhan dan perkembangan dalam masa hidupnya. Pertumbuhan berkaitan dengan perubahan dalam besar, jumlah, ukuran, dan fungsi tingkat sel, organ maupun individu, yang diukur dengan ukuran berat (gram, pound, kilogram), ukuran panjang $(\mathrm{cm}$, meter), umur tulang dan keseimbangan metabolik (retensi kalsium dan nitrogen tubuh). Pertumbuhan fisik merupakan hal yang kuantitatif yang dapat diukur. Indikator ukuran pertumbuhan meliputi meliputi perubahan tinggi badan, berat badan, gigi, struktur tulang,dan karakteristik seksual. Pertumbuhan dan perkembangan merupakan proses yang berkesinambungan, bersifat kontinyu dan pertumbuhan merupakan bagian dari proses perkembangan. ${ }^{(17)}$ Sedangkan perkembangan seperti perkembangan motorik, sensorik, koknitif dan psikososial bersifat kualitatif . (13)

Bayi merupakan masa kritis dan memerlukan perawatan khusus dan menyeluruh. Merawat bayi tidak cukup hanya dengan perawatan rutin, akan tetapi harus penuh kasih sayang. Tercapainya pertumbuhan dan perkembangan bayi yang optimal dipengaruhi oleh beberapa faktor yang saling berkaitan, yaitu faktor genetik, lingkungan, perilaku dan stimulasi. ${ }^{(2)}$

Salah satu cara untuk menstimulasi pertumbuhan dan perkembangan pada anak yaitu dengan menggunakan teknik baby solus per aqua (SPA). Penanganan secara nonfarmakologis terhadap peningkatan pertumbuhan dan perkembangan bayi yang aman bagi bayi adalah SPABayi. SPA berasal dari bahasa latin memiliki arti Solus (pengobatan/perawatan), per (dengan), aqua (air). Menurut Permenkes No.1205/Menkes/X/2004, SPA merupakan suatu upaya pelayanan kesehatan tradisional dengan perawatan menyeluruh dengan menggunakan keterampilan terapi air atau hidroterapi, massage (pijat), aromaterapi, serta ditambahkan pelayanan makanan, minuman serta olah aktifitas fisik yang dilakukan secara terpadu untuk meyeimbangkan tubuh, pikiran serta perasaan. Sedangkan perawatan kesehatan yang dikhususkan untuk bayi yaitu SPA Bayi, perawatan kesehatan modern yang dilakukan menggunakan air beserta perawatan pijat, menggunakan ramuan minyak aromaterapi.

SPA Bayi adalah perawatan yang dirancang untuk memberikan stimulasi positif pada bayi berusia 3 bulan atau jika bayi sudah bisa mengangkat kepala dengan kuat saat ditengkurapkan. Umumnya SPA Bayi dilakukan dengan pijat bayi yang disebut dengan touch therapy yang artinya adalah salah satu teknik yang mengkombinasikan manfaat fisik sentuhan manusia dengan manfaat emosional seperti ikatan batin (bonding). SPA Bayi merupakan rangkaian stimulasi tumbuh kembang anak dengan layanan pijat bayi. Perkembangan bayi merupakan kemampuan yang didapatkan dari kematangan suatu sistem syaraf pusat (otak). Adanya perkembangan ini sangat berkaitan dengan semakin bertambahnya keterampilan serta kecerdasan anak. Biasanya anak yang terlihat sehat maka perkembangannya pun juga demikian. Bayi yang diberikan SPA Bayi tentu akan berbeda tumbuh kembangnya dengan tumbuh kembang bayi yang tidak diberi SPA Bayi. Hal ini dikarenakan rangkaian SPA Bayi bertujuan merangsang saraf sensorik dan motorik bayi lebih dini dengan stimulus stimulus tertentu sehingga bayi dapat tumbuh aktif serta lebih optimal baik secara fisik maupun mentalnya. ${ }^{(18)}$

Seperti dengan namanya, SPA Bayi jenis ini melibatkan kekuatan fisik bayi di dalam air menggunakan pelampung di kepala. Biasanya Spa Bayi dilakukan di kolam renang permanen, portable atau di bak khusus yang terisi penuh dengan air. SPA Bayi dapat berlangsung kurang lebih 20 menit, Dua kali seminggu. Air yang digunakan untuk berenang cukup hangat, minimal bersuhu 33-350 $\mathrm{C}$ agar bayi tidak kedinginan dan rileks dan wajib dilakukan oleh terapis profesional seperti yang ada di Mhomecare. Saat di dalam air, bayi dapat menggerakkan kaki dan tangannya secara bebas sementara kepala tetap di atas pelampung. ${ }^{(16)}$

Menurut hasil penelitian menunjukkan 12 bayi yang mendapat SPA Bayi selama dua kali dalam seminggu mengalami kenaikan berat badan lebih banyak dibandingkan kelompok kontrol yang mendapat 3 kali SPA Bayi dan satu kali pijat bayi. Jika pada penelitian sebelumnya penilaian dilakukan dalam waktu satu minggu dengan memberikan perlakukan SPA Bayi dua kali dan pijat bayi satu kali, maka pada penelitian ini, dilakukan identifikasi perbedaan berat badan bayi sebelum dan sesudah mendapat SPA Bayi dengan frekuensi dua kali dalam waktu satu bulan (7), Sedangkan menurut hasil penelitan ${ }^{(6)}$ menunjukkan bahwa 13 dari 20 bayi dicurigai mengalami keterlambatan perkembangan dengan menggunakan skrinning menggunakan DDST II, dari hasil penelitian setelah dilakukannya SPA Bayi terdapat peningkatan hasil, awalnya 13 bayi masuk dalam kategori waspada, mengalami penurunan $10 \%$ menjadi hanya 11 bayi, sedangkan untuk kategori normal mengalami peningkatan data sebanyak $10 \%$ dari 5 bayi menjadi 7 bayi 
Berdasarkan latar belakang diatas maka penulisan tertarik untuk melakukan penelitian dengan judul "Pengaruh SPA Bayi terhadap Peningkatan Berat Badan Bayi Usia 4-6 Bulan di Wilayah Kerja Puskesmas Tapian Dolok Kabuaten Simalungun".

\section{Tujuan Penelitian}

1. Memperoleh gambaran tentang pengaruh SPA Bayi terhadap peningkatan berat badan usia 4 sampai 6 bulan.

2. Mengukur peningkatan berat badan bayi usia 4 sampai 6 bulan yang menerima dan $S P A$ Bayi maupun yang tidak menerima pemijatan dan $S P A$.

\section{Hipotesis}

Hipotesis dalam penelitian ini adalah Peningkatan Berat Badan Bayi yang mendapatkan Spa Bayi lebih besar dari pada bayi yang tidak mendapatkan SPA Bayi.

\section{METODE}

Jenis penelitian yang digunakan adalah dengan rancangan Quasi experimental dengan pendekatan pretestposttest kontrol group design. Pretest dilakukan pada kelompok intervensi dan kelompok kontrol menganai barat badan sebelum dilakukan SPA Bayi. Posttest akan dilakukan pada kedua kelompok setelah intervensi diberikan. Hasil sebelum dan sesudah intervensi akan dibandingkan antara kelompok intervensi dan kelompok kontrol. Penelitian dilakukan di Puskesmas Tapian Dolok Kecamatan Tapian Dolok Kabupaten Simalungun.

Penelitian ini adalah semua bayi yang berumur 4 sampai 6 bulan yang berada di Puskesmas Tapian Dolok Kecamatan Tapian Kabupaten Simalungun. Sampel penelitian adalah bayi berusia 4 sampai 6 bulan yang memenuhi kriteria inklusi dan eksklusi serta bersedia mengikuti penelitian dengan mengisi informed consent. Sedangkan untuk menentukan besar sampel penelitian dilakukan dengan menggunakan rumus besar sampel untuk menguji perbedaan rerata dua kelompok dengan tingkat kemaknaan $5 \%$ dan kekuatan uji 90\%. Penelitian ini menggunakan nilai standar deviasi dan peningkatan rata-rata kenaikan berat badan dari penelitian Bennett (2013). Hasil penelitian menunjukkan standar deviasi kenaikan berat badan sebesar 36,9 dengan selisih rerata kedua kelompok sebesar 48, 7 gram. Besar sampel didapatkan 12 responden. Pada penelitian ini jumlah sampel akan ditingkatkan menjadi 30 sesuai dengan minimal sampel yang dapat dianalisis secara statistik. Jadi kelompok perlakuan 30 bayi dan kelompok kontrol 30 bayi.

Dari data yang terkumpul diolah dan dianalisis secara deskriptif dan analitik. Analisis deskriptif dengan menghitung jumlah dan persentase untuk data kategori, sedangkan untuk data numerik dengan menghitung rata-rata, standar deviasi median dan rentang.

\section{HASIL}

Tabel 1. Distribusi Karakteristik Subjek Penelitian pada kedua Kelompok Penelitian.

\begin{tabular}{|c|c|c|c|c|c|}
\hline \multirow{3}{*}{ Karakteristik } & \multicolumn{4}{|c|}{ Kelompok } & \multirow{3}{*}{$\begin{array}{l}\text { Nilai } \\
\text { p *) }\end{array}$} \\
\hline & \multicolumn{2}{|c|}{ Eksperimen } & \multicolumn{2}{|c|}{ Kontrol } & \\
\hline & $(n=30)$ & $\%$ & $(n=30)$ & $\%$ & \\
\hline 1. Jenis Kelamin : & & & & & 0,791 \\
\hline Laki-laki & 19 & 32,0 & 18 & 30,0 & \\
\hline Perempuan & 11 & 18,0 & 12 & 20,0 & \\
\hline 2. Usia (Bulan) : & & & & & 1,0 \\
\hline 4 & 10 & 16,7 & 10 & 16,7 & \\
\hline 5 & 10 & 16,7 & 10 & 16,7 & \\
\hline 6 & 10 & 16,7 & 10 & 16,7 & \\
\hline
\end{tabular}

Karakteristik subyek penelitian Tabel 1. didefinisikan sebagai tujuan penelitian, subjek penelitian dikelompokan ke dalam dua kelompok sampel. Kelompok pertama adalah kelompok eksperimen (30 bayi) dan kelompok kedua adalah kelompok kontrol (30 bayi).

dapat diketahui bawha dari 60 bayi untuk karakteristik jenis kelamin laki-laki pada kelompok intervensi sebanyak 19 bayi (32\%) dan 18 bayi(30\%) pada kelompok kontrol. Sedangkan bayi dengan jenis kelamin perempuan yaitu sebanyak 11 bayi (18\%) pada kelompok intervensi dan 12 bayi (20\%) pada Kelompok kontrol dengan nilai $=1,000$ yang menunjukan bahwa tidak ada perbedaan karakteristik jenis kelamin antara kelompok kontrol dan kelompok intervensi (homogen). Sedangkan kelompok karakteristik usia bayi terdapat komposisi usia bayi merata yaitu bayi usia 4 sampai 6 bulan sebayak 10 bayi $(16,7 \%)$ pada kelompok intervensi dan kelompok kontrol dengan nilai $\mathrm{p}=1,000$ yang menunjukan bahwa tidak ada perbedaan karakteristik usia antara kelompok intervensi dan kelompok kontrol (homogen). 
Tabel 2. Pengaruh SPA terhadap Peningkatan Berat Badan Bayi. Deskriptif Statistik Berat Badan dari setiap Pengukuran.

\begin{tabular}{|c|c|c|c|c|c|}
\hline Berat Badan (gram & \multicolumn{4}{|c|}{ Ukuran statistik } & $\begin{array}{c}\text { Uji } \\
\text { Normalitas } \\
\text { data (nilai } \\
\text { p)* }\end{array}$ \\
\hline Data awal: & & & & & \\
\hline Eksperimen & 7486,7 & 627,8 & 7800 & $\begin{array}{c}6100- \\
8300\end{array}$ & 0,003 \\
\hline Kontrol & 7183,3 & 735,3 & 7150 & $\begin{array}{l}6000- \\
8300\end{array}$ & 0,039 \\
\hline $\begin{array}{l}\text { Pengukuran Minggu } \\
\text { ke 1: }\end{array}$ & & & & & \\
\hline Eksperimen & 7646,7 & 644,6 & 7900 & $\begin{array}{l}6150- \\
8450\end{array}$ & 0,003 \\
\hline Kontrol & 7300 & 736,7 & 7300 & $\begin{array}{l}6150- \\
8400\end{array}$ & 0,028 \\
\hline $\begin{array}{l}\text { Pengukuran Minggu } \\
\text { ke 2: }\end{array}$ & & & & & \\
\hline Eksperimen & 7805 & 674,3 & 8125 & $\begin{array}{l}6300- \\
8600\end{array}$ & 0,003 \\
\hline Kontrol & 7415 & 732,3 & 7450 & $\begin{array}{l}6250- \\
8550\end{array}$ & 0,063 \\
\hline $\begin{array}{l}\text { Pengukuran Minggu } \\
\text { ke } 3 \text { : }\end{array}$ & & & & & \\
\hline Eksperimen & 7956,7 & 687,9 & 8250 & $\begin{array}{l}6400- \\
8800\end{array}$ & 0,004 \\
\hline Kontrol & 7515 & 733 & 7550 & $\begin{array}{l}6400- \\
8650\end{array}$ & 0,055 \\
\hline $\begin{array}{l}\text { Pengukuran Minggu } \\
\text { ke } 4 \text { : }\end{array}$ & & & & & \\
\hline Eksperimen & 8140 & 683,6 & 8400 & $\begin{array}{c}6650- \\
9000\end{array}$ & 0,008 \\
\hline Kontrol & 7598,3 & 769,4 & 7675 & $\begin{array}{l}6000- \\
8700\end{array}$ & 0,15 \\
\hline $\begin{array}{c}\text { Kenaikan awal - post } 1 \text { : } \\
\text { Eksperimen } \\
\text { Kontrol } \\
\end{array}$ & $\begin{array}{c}160 \\
116,7 \\
\end{array}$ & $\begin{array}{l}57,8 \\
40,1 \\
\end{array}$ & $\begin{array}{l}150 \\
100 \\
\end{array}$ & $\begin{array}{l}50-300 \\
50-250 \\
\end{array}$ & $\begin{array}{c}0,018 \\
0 \\
\end{array}$ \\
\hline $\begin{array}{c}\text { Kenaikan awal - post } 2 \text { : } \\
\text { Eksperimen } \\
\text { Kontrol }\end{array}$ & $\begin{array}{l}318,3 \\
231,7\end{array}$ & $\begin{array}{c}212,3 \\
60,9\end{array}$ & $\begin{array}{l}375 \\
225\end{array}$ & $\begin{array}{c}-1200 \\
100-350\end{array}$ & $\begin{array}{c}0 \\
0,03\end{array}$ \\
\hline $\begin{array}{c}\text { Kenaikan awal - post } 3 \text { : } \\
\text { Eksperimen } \\
\text { Kontrol }\end{array}$ & $\begin{array}{c}470 \\
331,7\end{array}$ & $\begin{array}{c}229,9 \\
76\end{array}$ & $\begin{array}{l}500 \\
300\end{array}$ & $\begin{array}{c}-1300 \\
200-500\end{array}$ & $\begin{array}{c}0 \\
0,032\end{array}$ \\
\hline $\begin{array}{c}\text { Kenaikan awal - post } 4 \text { : } \\
\text { Eksperimen } \\
\text { Kontrol }\end{array}$ & $\begin{array}{c}653,3 \\
415\end{array}$ & $\begin{array}{l}244,6 \\
143,9\end{array}$ & $\begin{array}{l}700 \\
400\end{array}$ & $\begin{array}{c}-1400 \\
-900\end{array}$ & $\begin{array}{l}0 \\
0\end{array}$ \\
\hline
\end{tabular}

Pada Tabel 2. Tampak menyajikan deskriptif statistik dari berat badan bayi untuk kedua kelompok perlakuan pada berbagai waktu pengukuran. Hasil uji normalitas data dengan uji Shapiro-Wilk pada kelompok eksperimen dari setiap pengukuran maupun peningkatannya menunjukkan tidak berdistribusi normal $(\mathrm{p}<0,05)$; sedangkan pada kelompok kontrol yang datanya berdistribusi normal adalah pada pengukuruan Minggu ke 2, Minggu ke 3, dan pengukuran Minggu ke 4, sedangkan yang lainnya tidak berdistribusi normal. Untuk perbandingan berat badan bayi dari setiap pengukuran karena pada kelompok perlakuan tidak berdistribusi normal, maka uji statistik yang digunakan adalah uji non parametrik dengan uji Mann-Whitney.
Tabel 3. Perbandingan Berat Badan dari Berbagai Waktu Pengukuran pada kedua Kedua Kelompok Penelitian.

\begin{tabular}{|c|c|c|c|}
\hline \multirow[b]{2}{*}{$\begin{array}{l}\text { Berat badan } \\
\text { (gram) }\end{array}$} & \multicolumn{2}{|c|}{ Kelompok } & \multirow[b]{2}{*}{$\begin{array}{c}\text { Nilai } \\
\mathbf{p}^{*)}\end{array}$} \\
\hline & $\begin{array}{c}\text { Eksperimen } \\
(\mathbf{n}=\mathbf{3 0})\end{array}$ & $\begin{array}{l}\text { Kontrol } \\
(n=30)\end{array}$ & \\
\hline Data awal : & $\begin{array}{c}7800^{* * *} \\
(6100-8300)\end{array}$ & $\begin{array}{c}7150 \\
(6000- \\
8300)\end{array}$ & 0,185 \\
\hline $\begin{array}{l}\text { Pengukuran } \\
\text { Minggu ke } 1 \text { : }\end{array}$ & $\begin{array}{c}7900 \\
(6150-8450)\end{array}$ & $\begin{array}{c}7300 \\
(6150- \\
8400)\end{array}$ & 0,124 \\
\hline $\begin{array}{l}\text { Pengukuran } \\
\text { Minggu ke } 2 \text { : }\end{array}$ & $\begin{array}{c}8125 \\
(6300-8600)\end{array}$ & $\begin{array}{c}7450 \\
(6250- \\
8550)\end{array}$ & 0,059 \\
\hline $\begin{array}{l}\text { Pengukuran } \\
\text { Minggu ke } 3 \text { : }\end{array}$ & $\begin{array}{c}8250 \\
(6400-8800)\end{array}$ & $\begin{array}{c}7550 \\
(6400- \\
8650)\end{array}$ & 0,024 \\
\hline $\begin{array}{l}\text { Pengukuran } \\
\text { Minggu ke } 4 \text { : }\end{array}$ & $\begin{array}{c}8400 \\
(6650-9000)\end{array}$ & $\begin{array}{c}7675 \\
(6000- \\
8700)\end{array}$ & 0,008 \\
\hline \multicolumn{4}{|l|}{$\begin{array}{l}\text { Kenaikan (nilai } \\
\text { median) : }\end{array}$} \\
\hline Data awal - post 1 & 150 & 100 & 0,002 \\
\hline Data awal - post 2 & 375 & 225 & $<0,001$ \\
\hline Data awal - post 3 & 500 & 300 & $<0,001$ \\
\hline Data awal - post 4 & 700 & 400 & $<0,001$ \\
\hline
\end{tabular}

Pada Tabel 3. tampak pada data awal berat badan bayi tidak menunjukkan ada perbedaan yang bermakna ( $p>0,05$ ). Pada pengukuran minggu ke-1, dan minggu ke- 2 juga tampak berat bayi pada kedua kelompok perlakuan tidak bermakna, sedangkan pada pengukuran minggu ke - 3 dan minggu ke - 4 menunjukkan ada perbedaan yang bermakna $(\mathrm{p}<0,05)$; pada kelompok eksperimen nilai mediannya lebih tinggi bila dibandingkan dengan kelompok kontrol.

Selanjutnya, berdasarkan kenaikan berat badan terhadap berat badan awal, kenaikan pada pengukuran minggu ke 1, 2, 3 dan ke 4 menunjukkan ada perbedaan yang sangat bermakna $(\mathrm{p}<0,01)$. Pada pengukuran ke 4, pada kelompok eksperimen terjadi peningkatan berat badan 700 gram, sedangkan pada kelompok kontrol hanya 400 gram. 


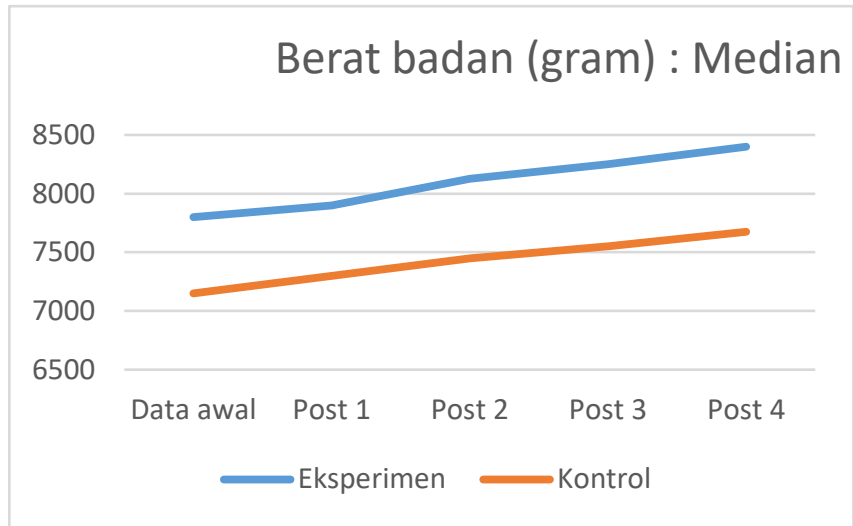

Gambar 1. Perbandingan rata-rata Berat badan dari berbagai waktu pengukuran pada kedua kelompok penelitian.

Pada Gambar 1. Merupakan hasil dari distribusi Ratarata berat badan bayi yang terjadi pada kedua kelompok pengamatannya, pada pengukuran minggu ke 1, 2, 3 dan minggu ke 4.

\section{PEMBAHASAN}

\section{Pengaruh Spa terhadap peningkatan berat badan dari setiap pengukuran}

Berdasarkan hasil analisis paa table 2. Dapat disimpulkan bahwa peningkatan berat badan pada kelompok intervensi lebih besar dari pada kelompok kontrol $(p<0,01)$. Hal ini membuktikan bahwa Spa pada bayi memengaruhi peningkatan berat badan bayi.

Secara teori dapat dijelaskan bahwa pada saluran cerna sepenuhnya otonom. Suplai saraf parasimpatis dihantarkan dari abdomen melalui saraf vagus. Saraf vagus adalah saraf kepala kesepuluh yang mengantarkan fungsi organ tubuh termaksud dibagian daa dan perut. Rangsangan pada saraf vagus (Saraf parasimpatis) akan merangsang lambung untuk mengeluarkan hormone gastrin. Hormone gastrin akan merangsang pengeluaran insulin, asam khidroklorida, pepsinogen, enzim pankreas, mukus, peningkatan aliran empedu hati dan merangsang mobilitas lambung. Hormon gastrin juga mempermudah relaksasi reseptif lambung (relaksasi sementara) sehingga lambung dapat menambah volumenya dengan sangat mudah tanpa peningkatan tekanan. Pengeluaran insulin akan mempermudah untuk memetabolisme glukosa. Sekresi asam hidrokloridam enzim pankreas, peningkatan aliran empedu hati akan mempermudah pencernaan makanan. Sehingga dengan adanya peningkatan lambung dan usus akan mempermudah pencernaan, mendorong makanan dan penyerapan nutrisi menjadi lebih baik. ${ }^{(4)}$

Hasil penelitian yan dilakukan oleh Lee, membuktikan bahwa pemijatan dan SPA Bayi yang dilakukan pada bayi prematur selama 10 hari dilakukan 1 kali/hari menunjukkan terdapat peningkatan tonus saraf vagus yang signifikan setelah pemijatan dan Spa dilakukan dari pada sebelum dilakukan pada kelompok intervensi. Beberapa penelitian juga menyatakan bahwa aktivitas vagus berhungan dengan peningkatan pertumbuhan bayi. Aktivitas vagus pada akhirnya akan merangsang motilitas gastric akan membuat bayi sering lapar, hal ini dapat memingkatkan penambahan berat badan pada bayi. ${ }^{(4)}$

Penelitian yang dilakukan oleh Jorgensen $\mathrm{R}^{(5)}$ kepada bayi 21 bayi dilakukan Spa selama 15 menit setiap hari selama 1 bulan. Hasil penelitian terdapat peningkatan berat badan, insulin dan IGF (Insulin Like Growth Faktor) pada kelompok intervensi. Peningkatan berat badan berhungan secara signifikan dengan peningkatan kadar Insulin dan IGF, Peningkatan aktivitas vagus dan motilitas gastic. Hal ini mempunyai kontribusi terhadap penyerapan makanan secara efektif.

Menurut hasil penelitian damayanti, pemberian $S P A$ Bayi berpengaruh terhadap peningkatan berat badan pada bayi dengan berat badan rendah usia 4-6 bulan dengan nilai $\rho>0,05$. Bayi yang diberikan Spa dengan berat badan rendah didapatkan hasil sebelum dilakukan perlakuan ratarata berat badan $5.15 \mathrm{~kg}$ dan setelah dilakukan perlakuan SPA Bayi selama 4 minggu dengan dosis 1 minggu $2 \mathrm{x}$ treatment didapatkan hasil kenaikan berat badan $6.00 \mathrm{~kg}$ yang baik dibandingkan kelompok massage dengan peningkatan rata-rata berat badan sebelum treatment $4.98 \mathrm{~kg}$ dan setelah diberikan treatment selama 1 bulan dengan dosis 1 minggu 2x didapatkan hasil peingkatan berat badan 5.43 $\mathrm{kg}$.

\section{Perbandingan Berat Badan dari Berbagai Waktu Pengukuran pada Kedua Kelompok Penelitian}

Agar pertumbuh dan perkembang secara optimal nutrisi dan kasih sayang yang cukup sangat dibutuhkan, nutrisi pada bayi 0-6 bulan dapat diperoleh dari pemberian Asi Eksklusif, selain itu bayi juga membutuhkan stimulasi yang tepat, karena anak yang banyak mendapatkan stimulasi akan lebih cepat berkembang daripada yang kurang atau bahkan tidak mendapat stimulasi. ${ }^{(13)}$

Hasil penelitian menunjukkan bahwa dengan SPA Bayi terdapat kenaikan berat badan terhadap berat badan awal, kenaikan pada pengukuran minggu ke 1,2, 3 dan ke 4 menunjukkan ada perbedaan yang sangat bermakna ( $p<0,01)$. Pada pengukuran ke 4, pada kelompok eksperimen terjadi peningkatan berat badan 700 gram, sedangkan pada kelompok kontrol hanya 400 gram.

SPA Bayi lebih terbukti meningkatkan berat badan karena pada saat SPA Bayi bayi mengeluarkan energi yang lebih besar pada saat melakukan berenang selama 20 menit dengan media air hangat sehingga bayi mengeluarkan energi dalam tubuh yang lebih banyak, setelah bayi melakukan treatment SPA Bayi nafsu makan bayi akan meningkat dan pola tidur bayi akan menjadi lebih baik sehingga bayi 
mengalami peningkatan berat badan yang lebih baik dari massage bayi yang bersifat relaksasi. ${ }^{(15)}$

Penelitian ini selaras dengan hasil penelitian yang dilakukan oleh Budi ${ }^{(3)}$ menunjukan bahwa SPA Bayi lebih terbukti bahwa kemampuan kontrol motorik akan berkembang lebih pesat dari pada jika ia hanya bermain di lantai, karena pada saat berenang di dalam air, efek gravitasi sangat rendah sehingga memungkinkan untuk bayi bergerak lebih banyak dan semua otot pun dapat bekerja dengan optimal. Bayi mengeluarkan energi yang lebih besar pada saat melakukan berenang selama 15 menit dengan media air hangat shingga bayi mengeluarkan energi dalam tubuh yang lebih banyak. Setelah bayi melakukan treatment SPA Bayi daya tanggap serta daya kerja otak dan otak akan menjadi lebih baik sehingga bayi mengalami peningkatan dalam pekembangan motorik baik kasar maupun halus.

Menurut hasil penelitian Puteri ${ }^{(10)}$ bahwa ada pengaruh pemberian teknik SPA Bayi terhadap kenaikan berat badan. Perawatan SPA Bayi salah satunya adalah pemijatan, hal ini sangat berpengaruh pada kenaikan berat badan bayi. Banyak penelitian mengungkapkan bahwa bayi yang diberikan perawatan SPA Bayi meningkatkan berat badan sekitar $47 \%$ per hari

Pentingnya memberikan stimulasi yang tepat bagi bayi untuk mendukung pertumbuhan pada masa tumbuh kembang dapat dilakukan dengan SPA Bayi. Peningkatan pertumbuhan yang terjadi pada bayi yang telah mengikuti SPA Bayi yaitu, nafsu makan bayi semakin meningkat sehingga berat badan bayi semakin bertambah dan bayi terlihat sehat serta mengalami peningkatan baik dari berat badan, tinggi badan, lingkar kepala jika dibandingkan dengan bayi dengan usia yang sma yang tidak diberi perlakuan SPA Bayi.

\section{KETERBATASAN PENELITIAN}

1. Penelitian ini hanya mengambil sampel pada waktu dan jumlah yang terbatas, sehingga untuk penelitian selanjutnya sebaiknya meneliti dengan jumlah sampel yang lebih banyak.

2. Penelitian ini menggunakan teknik Quasi experimental dalam pengambilan sampel karena peneliti memerlukan kerjasama dalam pengisian instrumen sehingga hanya Memilih ibu yang mempunyai bayi yang benar-benar bersedia bekerjasama. Untuk penelitian selanjutnya sebaiknya digunakan teknik pengambilan sampel yang lebih baik.

3. Pada penelitian ini pengukuran hanya dilakukan pada bayi usia 4 sampai 6 bulan dalam kurun wkatu 1 bulan.

\section{KESIMPULAN}

Setelah dilakukan penelitian tentang "Pengaruh SPA Bayi terhadap Peningkatan Berat Badan Bayi Usia 4-6 Bulan di Wilayah Kerja Puskesmas Tapian Dolok Kabuaten Simalungun". dapat diambil kesimpulan sebagai berikut :

1. Berdasarkan uji statistik yang dilakukuan diperoleh nilai $(\mathrm{p}<0,05)$ dapat disimpulkan terdapat penambahan berat berat badan pada bayi yang melalukan SPA dari pengukuran minggu 2, Minggu ke 3 dan pengukuran Minggu ke 4.

2. Berdasarkan uji statistik yang dilakukan diperoleh nilai $(\mathrm{p}<0,01)$ dapat disimpulkan ada perbandingan dari berbagai waktu pengukuran pada kelompok intervensi dan kelompok kontrol terhadap kenaikan berat badan dari berat badan awal, pengukuran minggu ke 1, 2, 3 dan mingggu ke 4. Pada kelompok intervensi terjadi peningkaan berat badan 700 gram, sedangkan pada kelompok kontrol hanya 400 gram.

\section{DAFTAR PUSTAKA}

1. Arikunto, S. 2002. Prosedur Penelitian Status Pendekatan Praktek Edisi Revisi V. Jakarta : Rineka Cipta.

2. Ambarwati F., Nasution N. Asuhan Keperawatan Bayi dan Balita. 1st ed. Yogyakarta: Cakrawala Ilmu; 2015.

3. Budi, U., et.al., 2015. Pengaruh Baby Spa Terhadap Perkembangan Motorik Kasar Pada Bayi Usia 3-6 Bulan Di Mom'me Organic Baby And Kids Spa. Semarang.

4. Guyton AC, Hall Je.Fisiologi Kedokteran. Alih Bahasa setiawan I. Tengadi LMAKA, Santoso A. Jakarta: EGC;2006.

5. Jorgensen R. Under-fives swimming as a site for capital building: supporting and enhancing the transitions. Aust J Early Child 2012; 37: 127-131.

6. Latorre-García J, Sánchez-López AM, Baena-García L et al. Physical activity in water to improve the psychomotricity in healthy babies. Babyswimming study protocol. JNNPR 2017; 2: 186-193. doi: https:// doi.org/10.19230/jonnpr.1345. 
7. Melati. 2017. Effect Of Solus Per Aqua (Spa) On Infant Weight. 3(4):438-442.

8. Notoatmodjo, S., 2016. Metodologi Penelitian Kesehatan. Jakarta: Rineka Cipta.

9. Roesli U. Pedoman Pijat Bayi. Jakarta: Trubus Agriwidya; 2014.

10. Puteri VTA, Taufik, S., \& Nurul M. Pengaruh Tekhnik Baby Spa terhadap Perkembangan Motorik dan Kenaikan Berat Badan Bayi. Mahakam Midwifery Journal(MMJ). 2019;4(1):324-9.

11. Permenkes. 2004. Peraturan Menteri Kesehatan Republik Indonesia Nomor 1205/MENKES/PER/X/2004. Pedoman Persyaratan Kesehatan Pelayanan Sehat Pakai Air (SPA).

12. Sugiono.2010. Metode Penelitian Kuantitatif Kualitatif dan R dan D. Bandung: Alfabeta.

13. Soetjiningsih, 2014. Pentingnya Stimulasi Dini Untuk Merangsang Perkembangan Bayi \& Balita Terutama pada Bayi Resiko Tinggi. Sari Pediatri. Vol. 8.

14. Scoefer Y, Zutavern A, Brockow I, Schafer T, Kramer U, Schaaf B, et al. 2007. Health risk of early swimming pool attendance. Int J Hyg Environ health.

15. Sutawijaya, Bagus. 2010. Bugar dan Fit dengan Terapi Air. Yogyakarta : Mediabaca Tri, Sunarsih. 2010.

16. Saphiranti, Dona dan Ginayatunisa. 2011. Mom and Baby SPA. Program Studi Sarjana Desain Interior, Fakultas Seni Rupa dan Desain (FSRD) ITB. Jurnal Tingkat Sarjana bidang Senirupa dan Desain.

17. Vivian, Nanny Lia. 2010. Asuhan Neonatus Bayi dan Blita. Jakarta : Salemba Medika.

18. Yahya, Nadjibah. 2011. Spa Bayi dan Anak. Solo : Megatraf. 